\section{Complete Life Cycle and Heat Tolerance of Dry Colonies of a Terrestrial Cyanobacterium, Nostoc sp. HK-01}

\author{
Shunta Kimura ${ }^{1}$, Kaori Tomita-Yokotani ${ }^{1 *}$, Hiroshi \\ Katoh $^{2}$, Seigo Sato', Masayuki Ohmori ${ }^{3}$. \\ ${ }^{1}$ Graduate School of Life and Environmental \\ Sciences, University of Tsukuba, Tsukuba, Ibaraki \\ 305-8572, Japan \\ ${ }^{2}$ Division of Plant Functional Genomics, Life \\ Science Research Center, Mie University, Tsu, Mie \\ 514-8507, Japan \\ ${ }^{3}$ Faculty of Science and Engineering, Chuo \\ University, Bunkyo-ku, Tokyo, 112-8551, Japan
}

\section{Abstract}

The exact life cycle of cells in a terrestrial cyanobacterium, Nostoc sp. HK-01 which has several different types of cells, was confirmed by microscopic observation. All of types of cells were individually observed during 30-days of liquid incubation. The germination process from akinetes was recognized twice during the incubation period. The contribution of extracellular polysaccharides, EPS, for tolerance to heat in the dried colonies of Nostoc sp. HK01 was also investigated. The survival rate of dried colonies of Nostoc sp. HK-01 with and without EPS were examined after exposure to temperatures at $100^{\circ} \mathrm{C}$. The contribution to heat tolerance of EPS was tested and verified by the cell staining method. The survival rate of both groups of cells, with EPS and without EPS, of Nostoc sp. HK-01 was not remarkably different and they both lived under these conditions for 12 hours. These results indicate that the contribution of EPS to their heat tolerance would be very low. The amounts of sucrose and trehalose in the dry colonies were investigated to determine the contribution to heat tolerance in akinete as a compatible solute. The amount of trehalose was lower than that of sucrose in the dry colonies. It can be assumed that trehalose did not contribute to their heat tolerance.(C2017 Jpn. Soc. Biol. Sci. Space; doi: 10.2187/bss.31.1

Keywords; compatible solute, cyanobacteria, extracellular polysaccharides, heat tolerance, life cycle of cell, Nostoc sp. HK-01

Received: July 4, 2016; Accepted: February 15, 2017

*To whom correspondence should be addressed:

Tel.: +81-(0)29-853-4617; Fax: +81-(0)29-853-7229;

E-mail: yokotani.kaori.fn@u.tsukuba.ac.jp

\section{Introduction}

The preparations for the establishment of a manned Mars mission have been starting and lots of results related to the mission have been accumulated (Badescu, 2009; Casaregola et al., 2009; Ehrenfreund et al., 2012; International Space Exploration Coordination Group, 2013; Salotti and Heidmann, 2014). As one of the aspects of a the mission, we have been focusing on the study of space agriculture for human habitation on Mars (Yamashita et al., 2006, 2009; Wada, 2007; Kanazawa et al., 2008). In the study of space agriculture, terrestrial cyanobacteria are the best candidates for initial organisms to introduce to Mars, because of their various abilities; photosynthesis, nitrogen fixation and drought tolerance (Ohmori et al., 2006; Obana et al., 2007; Yamashita et al., 2009; Garcia-Pichel, 2010; Hu et al., 2012; Katoh et al., 2012).

There is a terrestrial cyanobacterium, Nostoc sp. HK01, which was isolated and characterized from Nostoc commune crusts (Katoh et al., 2003). Arai et al., (2008) and Kimura et al. (2015b) found that Nostoc sp. HK-01 can grow for a period of 140 days, and also can survive for over eight years on Martian regolith simulant which does not include a carbon source or a nitrogen source. In addition, the cyanobacterium has high tolerances to several cosmic rays (Tomita-Yokotani et al., 2013). Nostoc sp. HK-01 may be suitable to create organic soil from Martian regolith (Arai et al., 2008; Arai, 2009; Oarga, 2009; Verseux et al., 2016). The result indicates that the cyanobacterium can also be used to add nutrition to harsh environments on Earth. There are many harsh environmental places for aerobes where temperatures are around $60^{\circ} \mathrm{C}$ even on the Earth (Gao, 1998). Kimura et al. (2015a) has found that only the akinetes in dry colonies of Nostoc sp. HK-01 have the ability to tolerate to heat. The mechanisms, however, have not yet been elucidated.

Aside from tolerances to heat, it has been investigated that the cyanobacterium, Nostoc sp. HK-01, has tolerances to desiccation, $\mathrm{NaCl}$ and vacuum (Arai et al., 2008; Yoshimura et al., 2012). In the case of tolerances to desiccation, $\mathrm{NaCl}$ and ultraviolet (UV), the contribution of EPS, extracellular polysaccharides, was deeply related to each tolerance, e.g., the chemicals in the EPS have the abilities to protect cells from damage by ultraviolet rays (Ehling-Schulz et al., 1997; Tamaru et al., 2005; Knowles and Castenholz, 2008; Yoshimura et al., 2012).

There are some reports that trehalose has an important role in the drought-resistance of Polyoedihum vanderplanki, Tardigrades and other organisms, as a compatible solute (Blomberg, 2000; Elbein et al., 2003; Sakurai et al., 2008; Wełnicz et al., 2011). Hershkovitz et al. (1991) reported that two kind of cyanobactria; Phormicium autumnale and Chroococcidiposis sp., accumulated trehalose and sucrose during a period of drought. Then, we tried to analyze the substances, trehalose and sucrose, for their contribution to heat tolerances as compatible solutes in Nostoc sp. HK-01. 


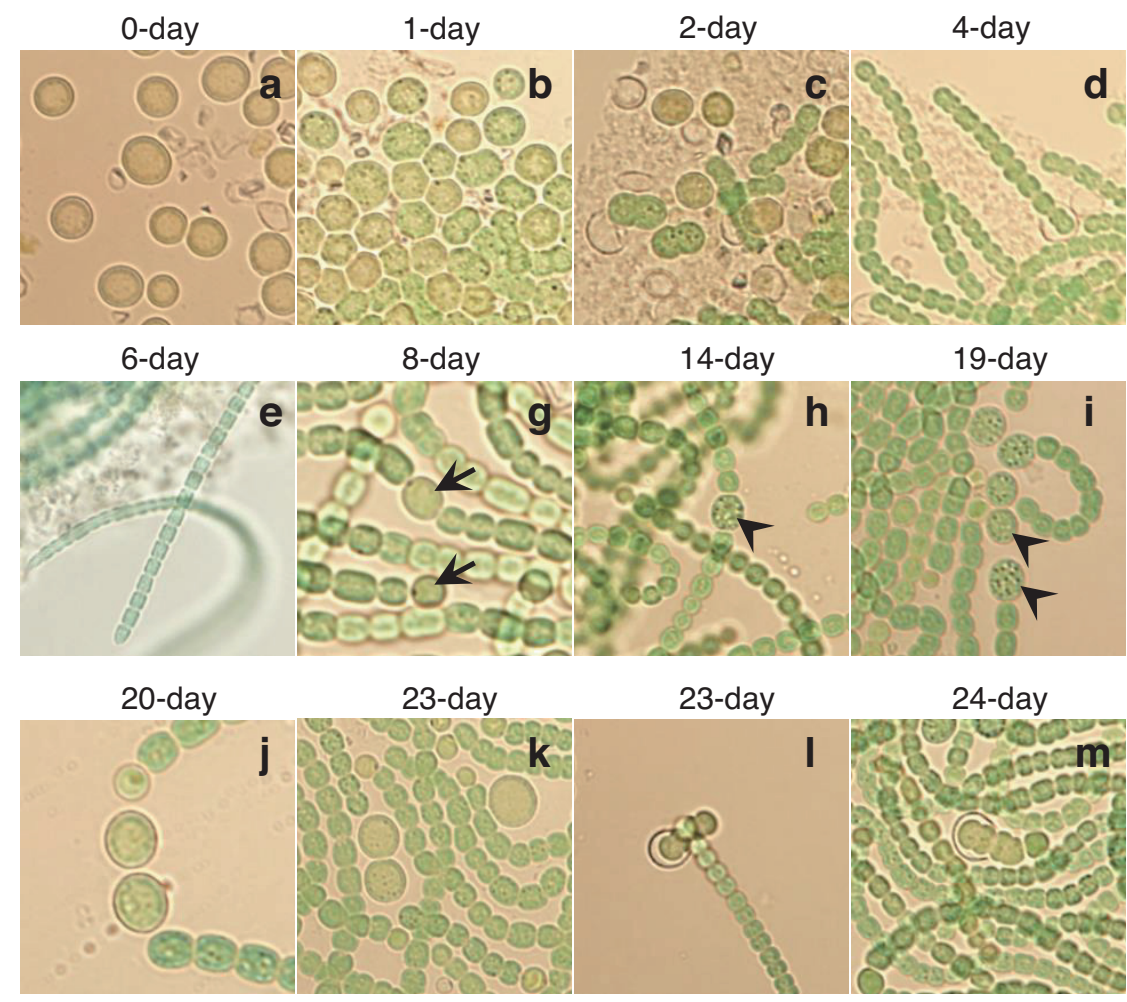

Fig. 1. Cell types of Nostoc sp. HK-01 during an incubation period of 24 days ( $\times 400$ ). Arrows ( $\mathbf{A})$ show heterocyst and arrowheads $(\boldsymbol{A})$ show the young akinetes. Bar shows $20 \mu \mathrm{m}$.

In this study, the exact life cycle of cells in a terrestrial cyanobacterium, Nostoc sp. HK-01 was determined. And the contribution of extracellular polysaccharides, EPS, for tolerance to heat in the dried colonies of Nostoc sp. HK-01 was also investigated. Furthermore, we tried to investigate the amounts of trehalose and sucrose as candidate compatible solutes in the cells which have heat tolerance.

\section{Material and Methods}

\section{Cyanobacterium}

A pure culture of a terrestrial cyanobacterium, Nostoc sp. HK-01 (NIES-2109, Algae Resource Database), was used as material in all experiments in this study (Kimura et al., 2015a).

\section{Incubation and preparation of dried colonies}

The preparation of dried colonies was conducted as described previously (Kimura et al., 2015a). $2.1 \times$ $10^{6}$ Nostoc sp. HK-01 cells were incubated in the liquid medium, BG-11 (Rippka et al., 1979), at $26^{\circ} \mathrm{C}$, under the light condition, $74.3 \pm 24.3 \mu \mathrm{mol} \mathrm{m}^{-2} \mathrm{~s}^{-1}$, with shaking at $120 \mathrm{rpm}$ (BW101, Yamato, Japan). After the incubation, the wet colonies were dried at $23^{\circ} \mathrm{C}$ with relative humidity around $30 \%$ in the dark. The colonies were naturally dried under those conditions until the weight was stable.

\section{The preparation of cells without EPS and} confirmation of cells without EPS

The preparation of cells without EPS was carried out according to the method of Tamaru et al. (2005) with modification. The dried colonies of Nostoc sp. HK-01 were hydrated with $25 \mathrm{mM}$ HEPES-NaOH $(\mathrm{pH}$ 7.0) and stored overnight at $25^{\circ} \mathrm{C}$. The hydrated colonies were concentrated to collect the cells at $2000 \times \mathrm{g}, 10 \mathrm{~min}$, at $20^{\circ} \mathrm{C}$ after they had been washed with 25 mM HEPES$\mathrm{NaOH}(\mathrm{pH} \mathrm{7.0)}$ two times. Astra-blue, which can stain sugars, was used for the confirmation of cells without EPS compared to the cells with EPS as a control (Tamaru et al., 2005; Hosonuma et al., 2009). After the removal of EPS, cells were re-dried at room temperature under dark condition, over 2 weeks. The control group was hydrated with BG-11 and stored overnight at $25^{\circ} \mathrm{C}$, and re-dried at room temperature under dark condition, over 2 weeks. Both dry colonies with and without EPS, ca. $100 \mu \mathrm{g}$ dry weight, were placed in an oven (WFO-450, Eyela, Japan), and exposed to $100^{\circ} \mathrm{C}$ for 1 to $12 \mathrm{~h}$.

\section{Pre-incubation for each survival experiment}

Dry and heated colonies were rehydrated by $500 \mu \mathrm{L}$ of BG-11 liquid medium. Each colony was kept in the dark at $30 \pm 2^{\circ} \mathrm{C}$ for 2 days and stirred for 1 minute by a mixer (TM-251, Iwaki, Japan), and used for the viability assay. 
Kimura, S. et al.

Table 1. Relative numbers of each cell type of Nostoc sp. HK-01 the during incubation period. Each value means average \pm standard error $(n=6)$. The graph is shown in Fig. 2.

\begin{tabular}{|c|c|c|c|c|}
\hline \multirow{2}{*}{$\begin{array}{l}\text { Incubation } \\
\text { period (Day) }\end{array}$} & \multicolumn{4}{|c|}{ Cell types } \\
\hline & Akinete & Vegetative Cell & Hormogonia & Heterocyst \\
\hline 0 & $100.0 \pm 0.0$ & $0.0 \pm 0.0$ & $0.0 \pm 0.0$ & $0.0 \pm 0.0$ \\
\hline 1 & $90.4 \pm 2.5$ & $9.6 \pm 2.5$ & $0.0 \pm 0.0$ & $0.0 \pm 0.0$ \\
\hline 2 & $29.6 \pm 4.4$ & $70.4 \pm 4.4$ & $0.0 \pm 0.0$ & $0.0 \pm 0.0$ \\
\hline 3 & $4.9 \pm 1.9$ & $95.1 \pm 1.9$ & $0.0 \pm 0.0$ & $0.0 \pm 0.0$ \\
\hline 4 & $2.8 \pm 1.8$ & $97.2 \pm 1.8$ & $0.0 \pm 0.0$ & $0.0 \pm 0.0$ \\
\hline 5 & $1.0 \pm 0.4$ & $99.0 \pm 0.4$ & $0.0 \pm 0.0$ & $0.0 \pm 0.0$ \\
\hline 6 & $0.4 \pm 0.2$ & $93.5 \pm 3.9$ & $6.1 \pm 3.8$ & $0.0 \pm 0.0$ \\
\hline 7 & $0.6 \pm 0.4$ & $88.6 \pm 6.3$ & $10.7 \pm 6.3$ & $0.0 \pm 0.0$ \\
\hline 8 & $0.6 \pm 0.3$ & $94.9 \pm 0.5$ & $0.0 \pm 0.0$ & $4.5 \pm 0.5$ \\
\hline 9 & $0.0 \pm 0.0$ & $85.9 \pm 3.6$ & $10.3 \pm 3.8$ & $3.9 \pm 0.6$ \\
\hline 10 & $0.0 \pm 0.0$ & $72.4 \pm 7.7$ & $24.3 \pm 8.3$ & $3.3 \pm 0.9$ \\
\hline 11 & $0.0 \pm 0.0$ & $71.0 \pm 3.1$ & $25.5 \pm 3.5$ & $3.5 \pm 0.9$ \\
\hline 12 & $0.0 \pm 0.0$ & $80.4 \pm 2.4$ & $14.0 \pm 3.2$ & $5.6 \pm 1.4$ \\
\hline 13 & $0.0 \pm 0.0$ & $90.6 \pm 1.4$ & $0.5 \pm 0.5$ & $8.9 \pm 1.4$ \\
\hline 14 & $0.1 \pm 0.1$ & $90.9 \pm 1.4$ & $1.6 \pm 1.6$ & $7.4 \pm 0.5$ \\
\hline 15 & $0.5 \pm 0.2$ & $90.7 \pm 1.1$ & $0.0 \pm 0.0$ & $8.8 \pm 1.0$ \\
\hline 16 & $0.1 \pm 0.1$ & $90.0 \pm 1.0$ & $0.8 \pm 0.8$ & $9.1 \pm 0.7$ \\
\hline 17 & $0.6 \pm 0.2$ & $92.9 \pm 0.8$ & $0.0 \pm 0.0$ & $6.5 \pm 0.9$ \\
\hline 18 & $0.7 \pm 0.3$ & $91.6 \pm 0.8$ & $0.4 \pm 0.4$ & $7.2 \pm 0.4$ \\
\hline 19 & $1.4 \pm 0.4$ & $92.1 \pm 0.9$ & $0.2 \pm 0.2$ & $6.3 \pm 0.6$ \\
\hline 20 & $1.3 \pm 0.5$ & $91.8 \pm 2.0$ & $2.1 \pm 1.3$ & $4.8 \pm 0.4$ \\
\hline 21 & $2.8 \pm 1.0$ & $89.6 \pm 1.3$ & $1.4 \pm 1.4$ & $6.2 \pm 0.3$ \\
\hline 22 & $2.3 \pm 0.9$ & $91.0 \pm 0.9$ & $1.3 \pm 1.3$ & $5.4 \pm 0.5$ \\
\hline 23 & $1.5 \pm 0.3$ & $94.0 \pm 0.8$ & $0.0 \pm 0.0$ & $4.5 \pm 0.6$ \\
\hline 24 & $1.5 \pm 1.1$ & $93.7 \pm 1.7$ & $0.6 \pm 0.6$ & $4.2 \pm 0.6$ \\
\hline 25 & $4.2 \pm 1.2$ & $79.1 \pm 5.0$ & $12.3 \pm 5.7$ & $4.4 \pm 0.5$ \\
\hline 26 & $1.7 \pm 0.5$ & $83.9 \pm 6.3$ & $8.0 \pm 6.5$ & $6.4 \pm 1.0$ \\
\hline 27 & $3.7 \pm 0.9$ & $84.9 \pm 2.0$ & $5.3 \pm 1.8$ & $6.1 \pm 0.7$ \\
\hline 28 & $3.0 \pm 0.7$ & $75.0 \pm 4.9$ & $17.4 \pm 5.6$ & $4.6 \pm 0.5$ \\
\hline 29 & $3.2 \pm 0.6$ & $88.3 \pm 1.7$ & $3.1 \pm 1.4$ & $5.4 \pm 0.5$ \\
\hline 30 & $2.7 \pm 0.8$ & $71.4 \pm 14.8$ & $23.0 \pm 15.8$ & $2.8 \pm 0.8$ \\
\hline
\end{tabular}

\section{The viability assay}

The viability assay was performed as described previously (Kimura et al., 2015a) using the FDA (Fluorescein diacetate) staining method (Jones and Senft, 1985; Mori et al., 2002; Arai et al., 2008). The viability assay was conducted at several stages to confirm the tolerance to heat.

At each tested stage, the $100 \mu \mathrm{L}$ FDA staining solution was added to the $200 \mu \mathrm{L}$ of suspended cells with water containing cyanobacteria, and mixed by shaking at $500 \mathrm{rpm}, 37^{\circ} \mathrm{C}$ for 10 minutes in dark conditions (M·BR-022UP, Taitec, Japan). After 5 minutes on ice, the cells were observed using a fluorescent microscope (BX50, Olympus, Japan), with a fluorescence NIBA filter (excitation wavelength, 470-490nm). The viable cells emitted green fluorescence during observation.

The observation of growth and each morphological cell type

The differentiation of akinetes, vegetative cells, heterocysts and hormogonia were observed by microscope (BX50, Olympus, Japan). 100 trichome cells were counted during the 0-7 day incubation period for calculation of growth. The number of observed individual types of cells was statistically counted on six random samplings of three $40 \times 40 \mu \mathrm{m}$ compartments of photomicrographs during the 30-day incubation period.

Preparation of the colonies with different ratio of akinete cells

The method for incubation of Nostoc sp. HK-01 was the same as described above. After the incubation, two groups of incubated wet colonies; one with a low number of akinete cells, the other with a high number of akinete cells, were obtained by counting all of cells. The number of all the cells and the number of akinete cells were counted from the photomicrographs, using Thoma's counting chamber (Nitirin). Groups of around five percent of akinete, and around $60 \%$ of akinete were prepared. The akinete content ratio (\%) was calculated as the number of akinete / the number of all cells $\times 100$.

\section{The amounts of trehalose and sucrose}

The colonies with each ratio of akinete were extracted with $80 \%$ ethanol at $65^{\circ} \mathrm{C}$. The solutions were evaporated 

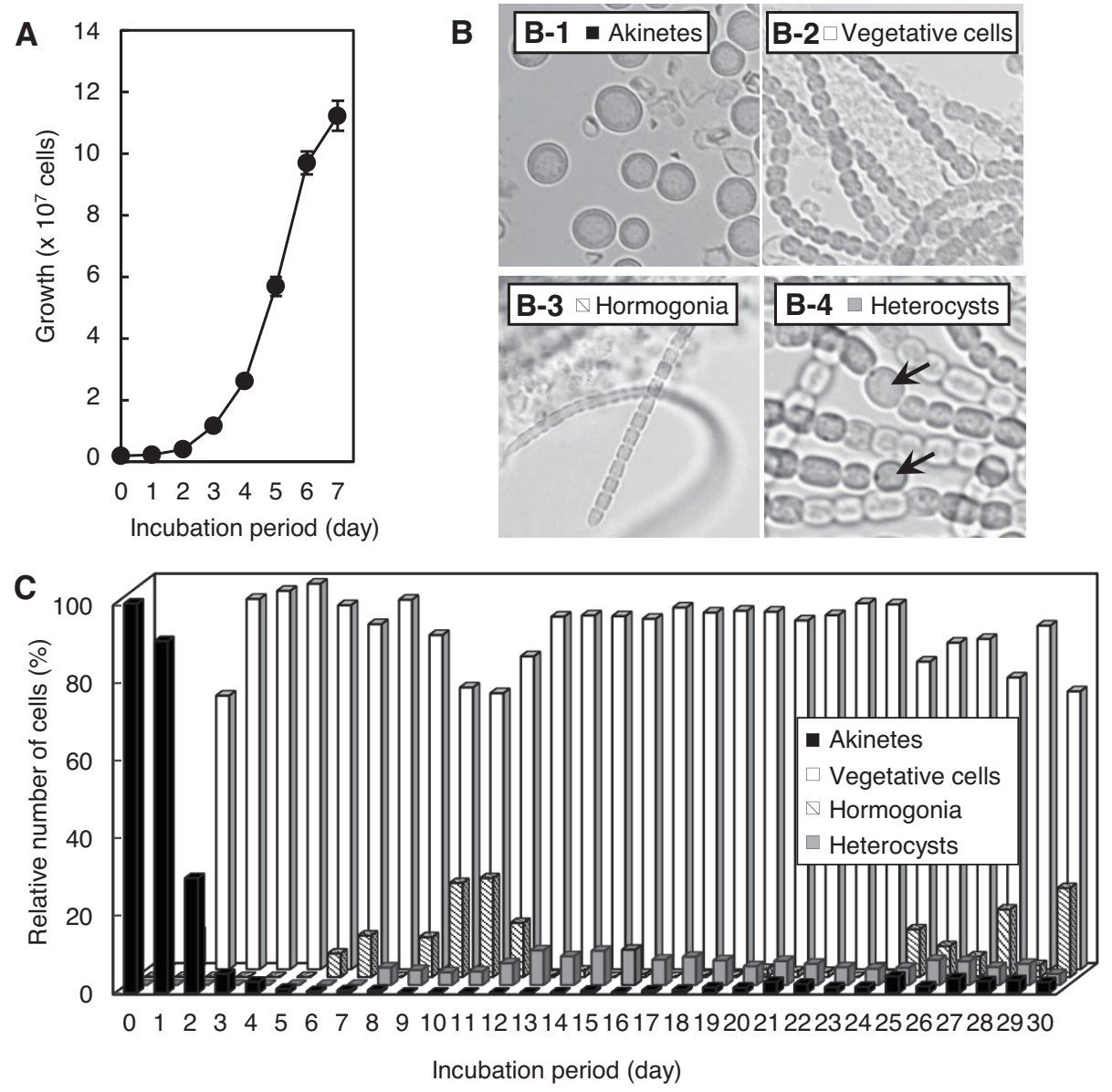

Fig. 2. Growth and each morphological cell type of Nostoc sp. HK-01. A: Growth of Nostoc sp. HK-01 during an incubation period of 7 days. B-1: Akinetes. B-2: Vegetative cells. B-3: Hormogonia. B-4: Heterocysts. C: Relative number of each cell types during incubation period of 30 days. $\square$ : Akinetes. $\square$ : Vegetative cells. $\nabla$ : Hormogonia. $\square$ : Heterocysts. The values are shown in Table 1 .

to dryness in vacuo at $38^{\circ} \mathrm{C}$. The fraction was purified using a $\mathrm{C}_{18}$ Sep-pak cartridge (Waters, USA) with a watermethanol solvent system by increasing the methanol concentration in the series of $0,50,100 \%(10 \mathrm{~mL}$ per step). The $0 \%$ methanol fraction was further purified through a $0.45 \mu \mathrm{m}$ filter (Tosoh, Japan) and analyzed by $\mathrm{LC}-\mathrm{ESI}^{+} / \mathrm{MS}$. Each extract was analyzed by LC-ESI $/ \mathrm{MS}$. The positive mode of LC-ESI/MS spectra and several fragments were analyzed with a Waters system (Waters micromass ZQ) consisting of a MS, (2690 Separation Module with a 996 Photodiode Array and a HPLC / PD detector) under the following operating conditions: capillary voltage, $3.5 \mathrm{kV}$; cone voltage, 30V; extractor voltage, $5 \mathrm{~V}$; lens voltage, $0.1 \mathrm{~V} \mathrm{RF}$; source temperature, $120^{\circ} \mathrm{C}$; desolvation gas flow, $300 \mathrm{~L} \mathrm{hr}^{-1}$.; cone gas flow, $50.0 \mathrm{~L} \mathrm{hr}^{-1}$.; column, TSKgel Amide80, Particle size: $3 \mu \mathrm{m}$, Dimension: $2.0 \mathrm{~mm}$, I.D. $\times 15 \mathrm{~cm}$, Tosoh; column Temp., $30^{\circ} \mathrm{C}$; solvent, $\mathrm{CH}_{3} \mathrm{CN}(80 / 20)$; frowrate, $0.2 \mathrm{~mL} \mathrm{~min}^{-1}$.

\section{Results and discussion}

To confirm the exact cellular life cycle of Nostoc sp. HK-01, all of types of cells in colonies of the strain during their life cycle were observed during a 30-day incubation period. Fig. 1 showed all types of the observed cells of Nostoc sp. HK-01 during a 24-day incubation period. There are only akinetes at the initial state, and a similar picture was obtained after 1-day of incubation (Fig. 1-a and $b$ ). The vegetative cells were not recognized until after 2-days of incubation and elongated vegetative cells were observed after 4-days of incubation (Fig.1-c and d). After around 6-days of incubation, hormogonia were observed (Fig.1-e and f). After the occurrence of hormogonia, heterocysts were recognized after 8-days of incubation (Fig. 1-g). Then, the young akinetes were differentiated among the elongated vegetative cells (Fig. 1-h and i). After that new matured akinetes (Fig. 1- j and k) were re-germinated, and the new vegetative cells were elongated again (Fig. 1-I and m). Fig. 2A shows the growth of Nostoc sp. HK-01. $2.1 \times 10^{6}$ cells were became $1.2 \times 10^{8}$ cells in 7 days of incubation. After 8 days of incubation, the number of trichome could not be counted because the division of trichome cells coincide with the differentiation of heterocyst or akinete cells. Annual changes of the number of each cell; akinetes (Fig. 2B-1), vegetative cells (Fig. 2B-2), hormogonia (Fig. 2B-3) and 




Fig. 3. The life cycle of cells of Nostoc sp. HK-01. Arrow (A) shows heterocyst. Arrowhead (A) shows young akinete.

heterocysts (Fig. 2B-4), were counted (Fig. 2C and Table 1). The cell types and time course of the number of all types of cells are shown in Fig. 2C. Kimura et al. (2015a) have already reported that only akinetes of Nostoc sp. HK-01 can live after they have been dried. As shown in Fig. $2 \mathrm{C}$, the relative number of akinetes was remarkably decreased around 4-days of incubation and the relative number of vegetative cells was increased along with a decrease in the number of akinetes, which indicates that some vegetative cells were germinated from akinetes. During the observation, some of the vegetative cells differentiated to hormogonia and heterocysts. Some akinetes developed among the vegetative cells (Fig. 1, Fig. 2 and Table 1). The existence of hormogonia was recognized after 10 to 11 days of incubation and the percentage of hormogonia was around $20 \%$, but the ratio of hormogonia was reduced to around one percent at day 13 and 14 of incubation. These results indicate that the hormogonia differentiated to be vegetative cells and furthermore the vegetative cells grew. The existence of heterocyst, which is a dead-end cell, has been recognized around 3 to $9 \%$ after 8 -days of incubation, which was observed in Nostoc sp. HK-01. These phenomena agree with several other reports (Adams and Duggan, 1999; Dworkin, 2006; Mateo et al., 2011).

The life cycle of cells in Nostoc sp. HK-01 was summarized as shown in Fig. 3. The confirmation of a detailed life cell cycle was first revealed in Nostoc sp. HK-01. The revealed cell life cycle of Nostoc sp. HK-01 is far different from that of Nostoc commune although Nostoc sp. HK-01 was isolated from the colony of Nostoc commune (Katoh et al., 2003). According to other researchers' lengthy studies, Nostoc commune does not have the ability of differentiation from their vegetative cells to akinetes (Cameron, 1962; Potts, 2000; Tamaru et al., 2005). Tamaru et al. (2005) have reported that the after the removal of EPS from the colonies of Nostoc commune, they did not even show a strong tolerance



Fig. 4. Microscopic observation of Nostoc sp. HK-01 after the astra-blue staining $(\times 400)$. A: cells with EPS, B: cells without EPS. Bar shows $20 \mu \mathrm{m}$.

to desiccation by air. Those results indicate that the character of Nostoc sp. HK-01 is far different from that of Nostoc commune.

The heat tolerance of Nostoc sp. HK-01 has already been reported but the contribution of extracellular polysaccharides, EPS, to tolerance to heat in the dried colonies has not yet been investigated. The preparation of cells without EPS was modified from the method of Tamaru et al. (2005). Fig. 4 showed the microscopic photographs of cells after the stain with astra-blue which can stain the sugars such as EPS. As shown in Fig. 4-B, treated cells were not stained with astra-blue. Thus, the method to remove EPS from the cells, used here, was proved to be useful in the case of Nostoc sp. HK-01.

The survival rates in dried colonies of Nostoc sp. HK01 with and without EPS after exposure to $100^{\circ} \mathrm{C}$ were shown in Fig. 5 and Table 2. The survival rates of both groups of cells at the time of exposure, with EPS and without EPS, of Nostoc sp. HK-01 were not remarkably different and the cells lived under exposure to heat for 0 to 12 hours $(p \geqslant 0.05)$ (Fig. 5 and Table 2). These results indicate that there are some functions in the cytoplasm of cells for tolerance to heat, which are different from that of the tolerance to $\mathrm{UV}, \mathrm{NaCl}$ or desiccation in Nostoc commune, Chroococcidiopsis sp. CCMEE 5056,

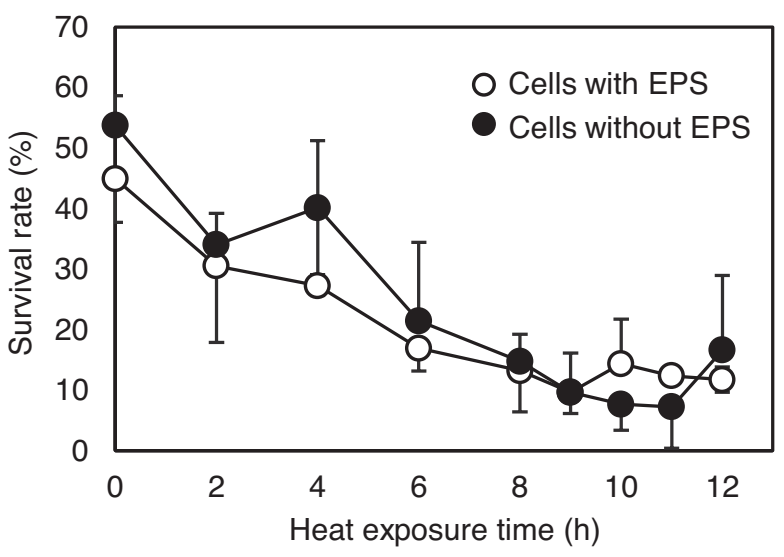

Fig. 5. The survival rates of Nostoc sp. HK-01, cells with EPS and cells without EPS, after exposure to dry heat $\left(100^{\circ} \mathrm{C}\right)$. The values are shown in Table 2. 
Table 2. The survival rates of Nostoc sp. HK-01, cells with EPS and cells without EPS, after exposure to dry heat $\left(100^{\circ} \mathrm{C}\right)$. The graph is shown in Fig. 5.

\begin{tabular}{|c|c|c|}
\hline \multirow{2}{*}{$\begin{array}{c}\text { Heat } \\
\text { exposure } \\
\text { time }(\mathrm{h})\end{array}$} & \multicolumn{2}{|c|}{ Survival rate of cells (\%)* } \\
\hline & With EPS & Without EPS \\
\hline 0 & $44.9 \pm 7.2$ & $53.8 \pm 4.9$ \\
\hline 2 & $30.6 \pm 12.6$ & $34.1 \pm 5.1$ \\
\hline 4 & $27.3 \pm 1.6$ & $40.2 \pm 11.0$ \\
\hline 6 & $16.9 \pm 3.8$ & $21.5 \pm 13.0$ \\
\hline 8 & $13.3 \pm 11.8$ & $14.8 \pm 4.5$ \\
\hline 9 & $9.7 \pm 6.0$ & $9.7 \pm 6.5$ \\
\hline 10 & $14.4 \pm 7.4$ & $7.7 \pm 4.3$ \\
\hline 11 & $12.4 \pm 1.2$ & $7.3 \pm 6.8$ \\
\hline 12 & $11.8 \pm 2.1$ & $16.3 \pm 12.4$ \\
\hline
\end{tabular}

*Each value means average \pm standard error $(n=3)$

Anabaena sp. PCC 7120 and Nostoc sp. HK-01 (EhlingSchulz et al., 1997; Tamaru et al., 2005; Knowles and Castenholz, 2008; Yoshimura et al., 2012). Our results proved that EPS can not protect the cells from dry heat at a temperature as high as $100^{\circ} \mathrm{C}$.

There are several functions related to dry heat tolerances in a water bear; Milnesium tradigradum, Richtersius coronifer and Ramazzottius varieornatus, and a sleeping chironomid; Polypedilum vanderplanki, which are anhydrobiotic organisms (Jönsson et al., 2008; Yamaguchi et al., 2012; Gusev et al., 2014). Milnesium tradigradum and Richtersius coronifer were exposed to space vacuum and two different UV-radiation spectral ranges for 10-days in low Earth orbit during the FOTON-M3 mission conducted by ESA, European Space Agency (Jönsson et al., 2008). After the exposure, it was found that Milnesium tradigradum and Richtersius coronifer could survive, although the detailed mechanisms of their survival have not yet been elucidated. Recently, Cytoplasmic Abundant Heat Soluble protein (CAHS), and Secretory Abundant Heat Soluble protein (SAHS), were identified in Ramazzottius varieornatus as the function related to tolerance to extreme heat desiccation (Yamaguchi et al., 2012).
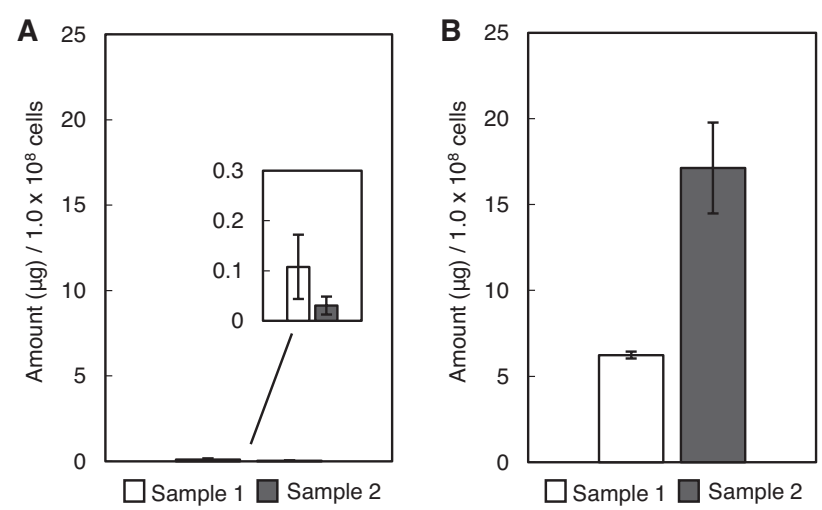

Fig. 6. The amount of trehalose $(A)$ and sucrose $(B)$ in sample 1 and $2(n=3)$. The ratio of akinete content in sample 1 was lower than that in sample 2 (Table 3 ).
Table 3. Akinete content ratio of Nostoc sp. HK-01 in sample 1 and 2 . The ratio of akinete content in sample 1 was lower than that in sample 2 .

\begin{tabular}{ccc}
\hline & Sample 1 & Sample 2 \\
\hline Exp. 1 & 5.22 & 59.89 \\
Exp. 2 & 4.91 & 53.27 \\
Exp. 3 & 3.51 & 62.44 \\
Ave. & 4.55 & 58.53 \\
SD & 0.91 & 4.73 \\
SE & 0.52 & 2.73 \\
\hline
\end{tabular}

We have analyzed the amounts of trehalose and sucrose in two cell groups; one had a low ratio of akinete cells which was around five percent, and the other had a high ratio of akinete cells which was around $60 \%$ (Table 3). As shown in Fig. 6, there is an exact accumulation of sucrose, particularly in the group with a high ratio of akinete cells, although there was low accumulation of trehalose. It has not been yet elucidated that sucrose may act as a compatible solute, because sucrose is an important substance for energy in all organisms. These results indicate that sucrose may have some role in dry heat tolerance, although trehalose does not have any role in heat tolerance in the case of Nostoc sp. HK-01. The details of the mechanisms of sucrose will have to be examined in the next step of our research.

In the present study, we have shown that Nostoc sp. HK-01 is far different from Nostoc commune, as described above. First of all, the life cycle of cells was different. For example, Nostoc sp. HK-01 has four types of cells and especially akinetes have high tolerance to dry heat at $100^{\circ} \mathrm{C}$. Tamaru et al. (2005) reported that the survival rate of cells without EPS in Nostoc commune was remarkably reduced even under the air-dried condition. Thus, the life cycle of cells and the tolerances to harsh environments were different. Katoh et al. (2003) reported that the DNA sequences of the 16S rRNA gene region and $\operatorname{trn} L$ (UAA)-intron region were determined and Nostoc sp. HK-01 is definitely classified in Nostoc species. The scientific information about this strain has been accumulated, especially about high tolerances to several extraterrestrial environments and their related chemicals. This strain has been used in the 'Tanpopo misson' (Yamagishi et al., 2007, 2009; Kawaguchi et al., 2016). Kimura et al. (2015ab) reported that this strain is suitable to introduce into Mars' environment as the first organism for the preparation of manned space activities. So, we are thinking that the scientific name of Nostoc sp. HK-01 should be changed according to additional results in the near future.

\section{Reference}

Adams, D.G. and Duggan, P.S. (1999) Tansley Review No. 107. Heterocyst and akinete differentiation in cyanobacteria. New Phytol., 144, 3-33.

Arai, M., Tomita-Yokotani, K., Sato, S., Hashimoto, H., Ohmori, M. and Yamashita, M. (2008) Growth of terrestrial cyanobacterium, Nostoc sp., on martian 
regolith simulant and its vacuum tolerance. Biol. Sci. Space, 22, 8-17.

Arai, M. (2009) Cyanobacteria for space agriculture on Mars. Biol. Sci. Space, 23, 203-210.

Badescu, V. (2009) Mars: prospective energy and material resources. Berlin, Heidelberg, Springer. pp. 718.

Blomberg, A. (2000) Metabolic surprises in Saccharomyces cerevisiae during adaptation to saline conditions: questions, some answers and a model. FEMS microbiol. lett., 182, 1-8.

Casaregola, C., Cesaretti, G. and Andrenucci, M. (2009) HiPER: A roadmap for future space exploration with innovative electric propulsion technologies. Proc. 31st Int. Electr. Propul. Conf., IEPC-2009-066. Michigan.

Cameron, R.E. (1962) Species of Nostoc vaucher occurring in the sonoran desert in Arizona. Trans. Am. Microsc. Soc., 81, 379-384.

Dworkin, M. (2006) Prokaryotic life cycles. In The Prokaryotes (pp. 140-166). Springer New York.

Ehling-Schulz, M., Bilger, W. and Scherer, S. (1997) UV$B$-induced synthesis of photoprotective pigments and extracellular polysaccharides in the terrestrial cyanobacterium Nostoc commune. J. Bacteriol., 179, 1940-1945.

Ehrenfreund, P., McKay, C., Rummel, J.D., Foing, B.H., Neal, C.R., Masson-Zwaan, T., Ansdell, M., Peter, N., Zarnecki, J., Mackwell, S., Perino, M.A., Billings, L., Mankins, J. and Race, M. (2012) Toward a global space exploration program: A stepping stone approach. Adv. Space Res., 49, 2-48.

Elbein, A.D., Pan, Y.T., Pastuszak, I. and Carroll, D. (2003) New insights on trehalose: a multifunctional molecule. Glycobiology, 13, 17-27.

Gao, K. (1998) Chinese studies on the edible blue-green alga, Nostoc flagelliforme: a review. J. Appl. Phycol., 10, 37-49.

Garcia-Pichel, F. (2010) Cyanobacteria. In The desk of encyclopedia of microbiology, second edition (ed. Schaechter, M.), 327-345. Oxford, Elsevier.

Gusev, O., Suetsugu, Y., Cornette, R., Kawashima, T., Logacheva, M.D., Kondrashov, A.S., Penin, A.A., Hatanaka, R., Kikuta, S., Shimura, S., Kanamori, H., Katayose, Y., Matsumoto, T., Shagimardanova, E., Alexeev, D., Govorun, V., Wisecaver, J., Mikheyev, A., Koyanagi, R., Fujie, M., Nishiyama, T., Shigenobu, S., Shibata, T.F., Golygina, V., Hasebe, M., Okuda, T., Satoh, N. and Kikawada, T. (2014) Comparative genome sequencing reveals genomic signature of extreme desiccation tolerance in the anhydrobiotic midge. Nat. Commun., 5, 4784.

Hershkovitz, N., Oren, A. and Cohen, Y. (1991) Accumulation of trehalose and sucrose in cyanobacteria exposed to matric water stress. Appl. Environ. Microbiol., 57, 645-648.

Hosonuma, Y., Gotoh, Y., Yasuda, M. (2009) Astra blue senshoku. Kensa to Gijutsu, 37, 666-670. [Article in Japanese]
Hu, C., Gao, K. and Whitton, B.A. (2012) Semi-arid regions and deserts. In Ecology of Cyanobacteria II (ed. Whitton, B. A.), 345-369. Dordrecht, Heidelberg, New York, London, Springer.

International Space Exploration Coordination Group. (2013) The Global Explorational Roadmap.

http://www.nasa.gov/sites/default/files/files/GER-2013_ Small.pdf

Jones, K.H. and Senft, J.A. (1985) An improved method to determine cell viability by simultaneous staining with fluorescein diacetate-propidium iodide. J. Histochem. Cytochem., 33, 77-79.

Jönsson, K.I., Rabbow, E., Schill, R.O., Harms-Ringdahl, M. and Rettberg, P. (2008) Tardigrades survive exposure to space in low Earth orbit. Curr. Boil., 18, R729-R731.

Kanazawa, S., Ishikawa, Y., Tomita-Yokotani, K., Hashimoto, H., Kitaya, Y., Yamashita, M., Nagatomo, M., Oshima, T., Wada, H. and Space Agriculture Task Force (2008) Space agriculture for habitation on Mars with hyper-thermophilic aerobic composting bacteria. Adv. Space Res., 41, 696-700.

Katoh, H., Shiga, Y., Nakahira, Y. and Ohmori, M. (2003) Isolation and characterization of a drought-tolerant cyanobacterium, Nostoc sp. HK-01. Microbes Environ., 18, 82-88.

Katoh, H., Furukawa, J., Tomita-Yokotani, K. and Nishi, Y. (2012) Isolation and purification of an axenic diazotrophic drought-tolerant cyanobacterium, Nostoc commune, from natural cyanobacterial crusts and its utilization for field reseach on soils polluted with radioisotopes. Biochem. Biophys. Acta, 1817, 14991505.

Kawaguchi, Y., Yokobori, S.I., Hashimoto, H., Yano, H., Tabata, M., Kawai, H. and Yamagishi, A. (2016) Investigation of the Interplanetary Transfer of Microbes in the Tanpopo Mission at the Exposed Facility of the International Space Station. Astrobiology, 16, 363-376.

Kimura, S., Tomita-Yokotani, K., Igarashi, Y., Sato, S., Katoh, H., Abe, T. Sonoike, K. and Ohmori, M. (2015a) The heat tolerance of dry colonies of a terrestrial cyanobacterium, Nostoc sp. HK-01. Biol. Sci. Space, 29, 12-18.

Kimura, Y., Kimura, S., Sato, S., Katoh, K., Abe, T., Arai, M. and Tomita-Yokotani, K. (2015b) Evaluation of a cyanobacterium, Nostoc sp. HK-01, as food material for space agriculture on Mars. Biol. Sci. Space, 29, 2431.

Knowles, E.L. and Castenholz, R.W. (2008) Effect of exogenous extracellular polysaccharides on the desiccation and freezing tolerance of rock-inhabiting phototrophic microorganisms. FEMS Microbiol. Ecol., 66, 261-270.

Mateo, P., Perona, E., Berrendero, E., Leganés, F., Martín, M. and Golubić, S. (2011) Life cycle as a stable trait in the evaluation of diversity of Nostoc from biofilms in rivers. FEMS Microbiol. Ecol., 76, 185-198.

Mori, F., Erata, M. and Watanabe, M.M. (2002) 
Cryopreservation of cyanobacteria and green algae in the NIES-collection. Microbiol. Cult. Coll., 17, 45-55.

Oarga, A. (2009) Life in extreme environments. Rev. Biol. Cienc. Terra, 9, 1-10.

Obana, S., Miyamoto, K., Morita, S., Ohmori, M. and Inubushi, K. (2007) Effect of Nostoc sp. on soil characteristics, plant growth and nutrient uptake. J. Appl. Phycol., 19, 641-646.

Ohmori, M., Yoshimura, H. and Higo, A. (2006) Riku ni sumu cyanobacteria. In Cyanobacteria ga hiraku atarashii sekai. (ed. Ikeuchi, M.), Seibutsu no Kagaku: Iden, 60, 52-57. [Article in Japanese]

Potts, M. (2000) Nostoc. In The ecology of cyanobacteria. (Eds. Whitton, B. A. and Potts, M.). Chapter 17, 465504, Kluwer academic publishers.

Rippka, R., Deruelles, J., Waterbury, J.B., Herdman, M. and Stanier, R.Y. (1979) Generic assignments, strain histories and properties of pure cultures of cyanobacteria. J. Gen. Microbiol., 111, 1-61.

Sakurai, M., Furuki, T., Akao, K.I., Tanaka, D., Nakahara, Y., Kikawada, T., Watanabe, M. and Okuda, T. (2008) Vitrification is essential for anhydrobiosis in an African chironomid, Polypedilum vanderplanki. Proc. Natl. Acad. Sci. U.S.A., 105, 5093-5098.

Salotti, J.M. and Heidmann, R. (2014) Roadmap to a human Mars mission. Acta Astronaut., 104, 558-564.

Tamaru, Y., Takani, Y., Yoshida, T. and Sakamoto, T. (2005) Crucial role of extracellular polysaccharides in desiccation and freezing tolerance in the terrestrial cyanobacterium Nostoc commune. Appl. Environ. Microbiol., 71, 7327-7333.

Tomita-Yokotani, K., Kimura, S., Kimura, Y., Igarashi, Y., Ajioka, R., Sato, S., Katoh, H. and Baba, K. (2013) Dried colony in cyanobacterium, Nostoc sp. HK-01: The several high environment tolerances for Tanpopo mission. The International Astrobiology Workshop 2013, poster session, 1033.

Verseux, C., Baqué, M., Lehto, K., de Vera, J.P.P., Rothschild, L.J. and Billi, D. (2016) Sustainable life support on Mars-the potential roles of cyanobacteria. Int. J. Astrobiology, 15, 65-92.

Wada, H. (2007) Agriculture on Earth and on Mars. Biol. Sci. Space, 21, 135-141. [Article in Japanese with English summary]

Wełnicz, W., Grohme, M.A., Kaczmarek, Ł., Schill, R.O. and Frohme, M. (2011) Anhydrobiosis in tardigrades: the last decade. J. Insect Physiol., 57, 577-583.

Yamagishi, A., Yano, H., Okudaira, K., Kobayashi, K., Yokobori, S., Tabata, M. and Kawai, H. (2007) TANPOPO: Astrobiology exposure and micrometeoroid capture experiments. Biol. Sci. Space, 21, 67-75. [Article in Japanese with English summary]

Yamagishi, A., Yano, H., Okudaira, K., Kobayashi, K., Yokobori, S.I., Tabata, M., Kawai, H., Yamashita, M., Hashimoto, H., Naraoka, H. and Mita, H. (2009) TANPOPO: astrobiology exposure and micrometeoroid capture experiments. Trans. Jpn. Soc. Aeronaut. Space Sci., 7, Tk_49-Tk_55.
Yamaguchi, A., Tanaka, S., Yamaguchi, S., Kuwahara, H., Takamura, C., Imajoh-Ohmi, S., Horikawa, D.D., Toyoda, A., Katayama, T., Arakawa, K., Fujiyama, A., Kubo, T. and Kunieda, T. (2012) Two novel heatsoluble protein families abundantly expressed in an anhydrobiotic tardigrade. PLoS one, 7, e44209.

Yamashita, M., Ishikawa, Y., Kitaya, Y., Goto, E., Arai, M., Hashimoto, H., Tomita-Yokotani, K., Hirafuji, M., Ohmori, K., Shiraishi, A., Tani, A., Toki, K., Yokota, $\mathrm{H}$. and Fujita, O. (2006) An overview of challenges in modeling heat and mass transfer for living on Mars. Ann. N. Y. Acad. Sci., 1077, 232-243.

Yamashita, M., Hashimoto, H. and Wada, H. (2009) Onsite resources availability for space agriculture on Mars. In Mars (ed. Badescu, V), Chapter 18, 517-542. Berlin, Heidelberg, Springer.

Yoshimura, H., Kotake, T., Aohara, T., Tsumuraya, Y., Ikeuchi, M. and Ohmori, M. (2012) The role of extracellular polysaccharides produced by the terrestrial cyanobacterium Nostoc sp. strain HK-01 in $\mathrm{NaCl}$ tolerance. J. Appl. Phycol., 24, 237-243. 